Columbia Law School

Scholarship Archive

2003

\title{
The Mechanisms of Market Efficiency Twenty Years Later: The Hindsight Bias
}

Ronald J. Gilson

Columbia Law School, rgilson@law.columbia.edu

Reinier Kraakman

Harvard Law School, kraakman@law.harvard.edu

Follow this and additional works at: https://scholarship.law.columbia.edu/faculty_scholarship

Part of the Banking and Finance Law Commons, Law and Economics Commons, and the Securities Law Commons

\section{Recommended Citation}

Ronald J. Gilson \& Reinier Kraakman, The Mechanisms of Market Efficiency Twenty Years Later: The Hindsight Bias, 28 J. CoRP. L. 715 (2003).

Available at: https://scholarship.law.columbia.edu/faculty_scholarship/1299

This Article is brought to you for free and open access by the Faculty Publications at Scholarship Archive. It has been accepted for inclusion in Faculty Scholarship by an authorized administrator of Scholarship Archive. For more information, please contact scholarshiparchive@law.columbia.edu. 


\title{
The Mechanisms of Market Efficiency Twenty Years Later: The Hindsight Bias
}

\author{
Ronald J. Gilson* and Reinier Kraakman**
}

I. INTRODUCTION

II. Putting MOME in an Intellectual Context: The Rise of Modern

FINANCE

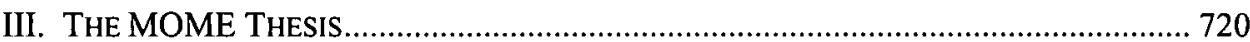

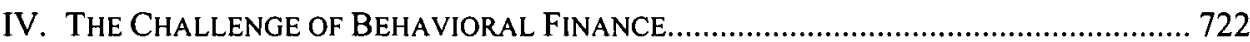

V. A Tentative Assessment of the Behavioral Finance Principles................. 731

A. The Investor Irrationality Principle ............................................................... 731

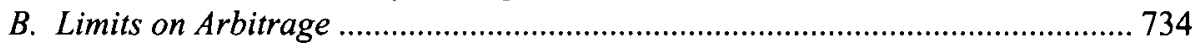

VI. How Well Does MOME Stand Up to Behavioral Finance? Good News

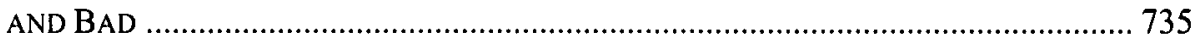

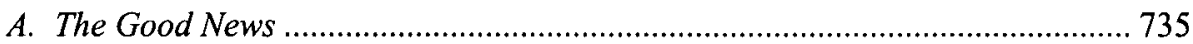

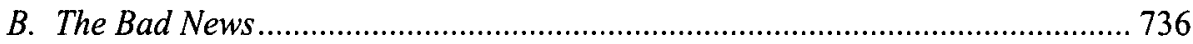

VII. The Future of BeHAVIORAL FinANCE: RESEARCH AND POLICY IMPLICATIONS ... 737

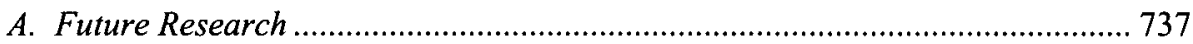

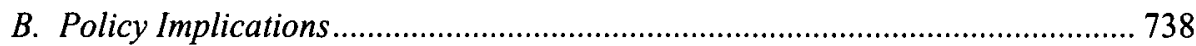

1. Where Behavioral Finance Can Guide Reform ..................................... 738

2. The Limits of Behavioral Finance as a Policy Tool .................................... 739

3. The Takeover Debate and the Limits of Behavioral Finance ...................... 739

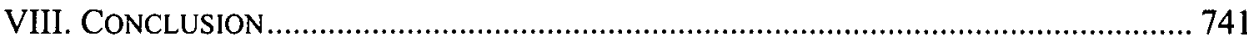

\section{INTRODUCTION}

This is a propitious time to revisit The Mechanisms of Market Efficiency

* Meyers Professor of Law and Business, Stanford Law School, and Stern Professor of Law and Business, Columbia Law School.

** Ezra Ripley Thayer Professor of Law, Harvard Law School. We are grateful to Donald Langevoort and Hillary Sale for suggesting a symposium on the Mechanisms of Market Efficiency in the first place, and to the Journal of Corporation Law, the University of lowa School of Law, and the Sloan Foundation for their financial support for the symposium that this issue presents, for their cooperation in producing this issue, and for their generous hospitality in Iowa City. Participants at the symposium and a Columbia Law School corporate faculty workshop, as well as Bernard Black, Melvin Eisenberg, Allen Ferrell, Jeffrey Gordon, Zohar Goshen, Samuel Issacharoff, Michael Klausner provided perceptive comments on an early version of this Article. The Article is better for their contributions; the remaining failings belong to the authors. This Article originated in a lecture given at the symposium and maintains some of the informality of that format. 
("MOME"). ${ }^{1}$ We began that project some twenty years ago, as newly minted corporate law academics ${ }^{2}$ trying to understand what to make of a large empirical literature proclaiming the efficiency of the U.S. stock market. In an observation then offered as a simple description of the state of play, Michael Jensen had announced that "there is no other proposition in economics which has more solid empirical evidence supporting it than the Efficient Market Hypothesis"3 ("EMH"). But if this were so, it seemed to us that it could not be because market efficiency was a physical property of the universe arising, like gravity, in the milliseconds following the big bang. Rather, the prompt reflection of publicly available information in a security's price had to be the outcome of institutional and market interactions whose proper functioning necessarily depended on the character of those institutions. ${ }^{4}$ Thus, MOME represented the efforts of two young scholars to understand the institutional underpinnings of the empirical phenomenon called market efficiency.

We concluded that the level of market efficiency with respect to a particular fact is dependent on which of a number of mechanisms-universally informed trading, professionally-informed trading, derivatively informed trading, and uninformed tradingoperated to cause that fact to be reflected in market price. Which mechanism was

1. Ronald J. Gilson \& Reinier Kraakman, The Mechanisms of Market Efficiency, 70 VA. L. REV. 549 (1984). MOME is pronounced "mommy" - an acronym meant to evoke a memory of warm maternal feelings.

2. Gilson had joined the Stanford Law School faculty in 1979; Krakman had joined the Yale Law School faculty in 1980. The project began while Gilson was a visiting professor at Yale Law School in 1982.

3. Michael C. Jensen, Some Anomalous Evidence Regarding Market Efficiency, 6 J. FiN. ECON. 95, 95 (1978).

4. We should be clear at the outset that we are addressing here, and addressed in MOME, the phenomenon of informational efficiency. It is now commonplace to distinguish fundamental efficiency-that market price represents the best current estimate of the present value of the future cash flow associated with an asset-from informational efficiency, that is, the absence of a profitable trading strategy based on publicly available information. Although this is a longer discussion than is appropriate here, we remain skeptical of the analytical foundations of the distinction. A stock price is efficient with respect to a particular information set. The assertion that fundamental value differs from an informationally efficient market price must mean one of two things. Either the market is inaccurately assessing currently available information, in which case a profitable trading opportunity in fact exists (unless there is a breakdown in the arbitrage mechanism, see infra text accompanying notes 38-61), or someone has additional, non-public, information (including a better asset pricing model) that demonstrates the inaccuracy of the current stock price-a circumstance that plainly does not call into question the market's semi-strong form efficiency. Operationally, the distinction is posed in terms of whether there is an institution other than the market whose estimates of current value we believe are systematically better than the market's (assuming private information is divulged). For example, do we imagine that an investment banker's fairness opinion is likely to be a better predictor? Compare the Delaware Supreme Court's unexamined commitment to the discoverability of fundamental value if one only asks an investment banker in Smith v. Van Gorkom, 488 A.2d 858 (Del. 1985) (failure of board to secure a fairness opinion was compelling evidence of violation of duty of care) with the Chancery Court's skepticism of investment bankers' valuation opinions in Paramount Communications, Inc. v. Time Inc., Fed. Sec. L. Rep. (CCH) 1 94,514 (Del. Ch. 1989, aff'd 571 A.2d 1140 (Del. 1990)) (investment banker opinion reflecting "a range that a Texan might feel at home on"). Or that a judge's estimate following evaluation of dueling expert reports is likely to be more accurate? If no existing institution will systematically better predict the fundamental value of a security on the available information, the distinction between informational efficiency and fundamental efficiency smacks of the Nirvana fallacy. Professor Allen advises that this analysis identifies us as "epistemological materialists." William T. Allen, Securities Markets as Social Products: The Pretty Efficient Market Hypothesis, 28 J. CoRP. L. 551 (2003). If we were choosing a label to dignify our effort, we'd lean toward calling it a pragmatic rejection of a Platonic form of fundamental value, but we appreciate Professor Allen's effort on our behalf. 
operative, in turn, depended on the breadth of the fact's distribution, which in turn depended on the cost structure of the market for information. The lower the cost of information, the wider its distribution, the more effective the operative efficiency mechanism and, finally, the more efficient the market.

Revisiting this framework is particularly appropriate because we are now experiencing the early stages of a quite different framework for evaluating the efficiency of the stock market, also supported by a growing number of empirical studies and also accompanied by an expansive description of the literature's reach by another respected Harvard economist. ${ }^{5}$ The new framework is styled "behavioral finance" and its ascent and market efficiency's descent is recounted by Andrei Shleifer: "Whatever the reason why it took so long in practice, the cumulative impact of both [behavioral finance] theory and the evidence has been to undermine the hegemony of the EMH ...." Michael Jensen's 1978 statement of the empirical support for market efficiency is now proffered with a tone somewhere between irony and condescension. ${ }^{7}$

The movement from Jensen's to Shleifer's formulation over twenty years surely merits a reconsideration of the substance and implications of market efficiency for legal and public policy, a task that the interesting papers in this symposium pursue with vigor. Although no longer new to the academy, ${ }^{8}$ in the end we remain convinced that how quickly and accurately the stock market reflects information in the price of a security is a function of the performance of institutions. In what follows we offer a brief, appropriately tentative assessment of the fit of behavioral finance with the framework developed twenty years ago in MOME, and an even briefer and more tentative evaluation of the policy implications arising from the behavioral finance framework.

In Part I, we put market efficiency in an intellectual context-as part of the shift of finance from description to applied microeconomics that also included the development of the Capital Asset Pricing Model and the Miller-Modigliani Irrelevancy Propositions, and ultimately gave rise to the award of three Nobel Prizes. Part II briefly recounts the MOME thesis, and Part III describes the challenge of behavioral finance. In Part IV, we offer our assessment of the central principles that drive behavioral finance and in Part V evaluate how the MOME thesis stands up to the challenge. In Part VI we stick our necks out a little, offering some MOME-based predictions about where it is likely that behavioral finance will and will not have significant policy implications. Part VII concludes.

\section{Putting MOME in an Intellectual Context: The Rise of Modern Finance}

MOME was written in response to the first spillover of finance into another discipline. Thus, to place MOME in its proper context we first need a snippet of

5. To be entirely accurate, Jensen was still at the University of Rochester at the time he wrote his now familiar assessment of market efficiency.

6. ANDREI SHLEIFER, INEFFICIENT MARKETS 23 (2000).

7. See, e.g., Lawrence A. Cunningham, Behavioral Finance and Investor Governance, 59 WASH. \& LEE L. REV. 767, 773 (2002) ("[Jensen's statement] was not an overly broad claim at the time perhaps, but with the passing of the years and the emergence of newer studies, one continues to wonder whether the claim said more about the social sciences than it did about the EMH [efficient market hypothesis].").

8. Much to our discomfort, one of the authors whose paper is included in this volume announced at the symposium that he was still in grade school when MOME was published. 
intellectual history-a capsule account of the development of modern finance. The nature of that development set the stage for MOME and, we will argue, for the important recent work in behavioral finance.

A fair place to begin is 1960 . The Journal of Finance was then only eight years old and, according to a popular historian of modern finance's early years, to that date had published no "more than five articles that could be classified as theoretical rather than descriptive." 9 Thus, it was hardly surprising that a generation of younger economists, intent on transforming finance into a mathematically rigorous branch of microeconomics, was focusing on developing theories that might explain description. Science involves empirically testing hypotheses, but formulating hypotheses requires an animating theory.

For present purposes, we will focus on three bodies of theory that arose in the period from the late 1950 s to the early 1970s. These sought to state rigorously how capital assets are priced, whether a corporation's choice of which capital assets to issue affects the corporation's value, and whether the market price of capital assets reflects all available information concerning their value. These three familiar theories-the Capital Asset Pricing Model, ${ }^{10}$ the Miller-Modigliani Irrelevance Propositions, ${ }^{11}$ and the Efficient Capital Market Hypothesis ${ }^{12}$ - shared a critical common methodology. The theories' rigor is achieved through an extensive set of perfect markets assumptions-in essence, rational investors, perfect information, and no transaction costs.

Start with the Capital Asset Pricing Model (CAPM). If one assumes that all unsystematic risk can be diversified away, what else but systematic risk could affect the price of capital assets? If investors need not bear unsystematic risk, then investors who do not bear it will require the lowest return (pay the highest price) for a capital asset, thereby setting the asset's price. CAPM simply takes the next step of identifying the systematic risk that matters to investors with the covariance of an asset's returns with those of the market-i. ə., beta. Given these assumptions, CAPM is, in short, a tautology.

The Miller-Modigliani Irrelevance Propositions share the same conceptual structure. That the choice of a debt-equity ratio does not affect firm value is, in Miller's words thirty years later, "an implication of equilibrium in perfect capital markets." 13 Like CAPM, the perfect capital market assumptions result in the Irrelevance Propositions appearing tautological. Think of a simple $\mathrm{T}$ diagram, with assets on one side and ownership interests - debt and equity - on the other. The balance sheet balances because of another tautology: the total value of the assets corresponds to the total ownershipdebt and equity-interests. Why then should the divisions on the right side of the balance sheet-the manner in which ownership interests are divided-affect the left side of the

9. Peter L. Bernstein, Capital ideas: The improbable Origins of Modern Wall Street 42 (1992). Bernstein's history, complete with personalities, is an entertaining account of the rise of modern finance.

10. William Sharpe, Capital Asset Prices: A Theory of Market Equilibrium Under Conditions of Risk, 19 J. FIN. 425 (1964).

11. Franco Modigliani \& Merton H. Miller, The Cost of Capital, Corporation Finance, and the Theory of Investment, 48 AM. ECON. REV. 261 (1958); Merton H. Miller \& Franco Modigliani, Dividend Policy, Growth, and the Valuation of Shares, $34 \mathrm{~J}$. Bus. 411 (1961). (1970).

12. Eugene F. Fama, Efficient Capital Markets: A Review of Theory and Empirical Work, 25 J. FIN. 383

13. Merton H. Miller, The Modigliani-Miller Propositions After Thirty Years, 2 J. ECON. PERSP. 99,99 (1988). 
balance sheet - that is, the value of the assets? ${ }^{14}$ If for some reason debt or equity was mispriced, arbitrage would restore the proper relation, so that increasing the amount of lower cost debt would result in an offsetting increase in the cost of equity and vice versa.

The Efficient Capital Market Hypothesis ("ECMH") also builds on perfect market assumptions. Commenting on Fama's 1970 seminal review article, William Sharpe stated: "Simply put, the thesis is this: in a well-functioning market, the prices... [of securities] will reflect predictions based on all relevant and available information. This seems almost trivially self-evident to most professional economists-so much so, that testing seems rather silly." 15 William Beaver made much the same point ten years later: "Why would one ever expect prices not to 'fully reflect' publicly available information? Won't market efficiency hold trivially?"16

In addition to its prediction of the information content of stock prices, the ECMH also played a critical integrative role, providing the necessary link between asset pricing and capital structure choice through the medium of market prices. Both CAPM and the Modigliani-Miller propositions depend on an arbitrage mechanism for their proof: mispricing will be traded away. But for arbitrage to be triggered by mispricing, market prices must be reasonably informative. Thus, along this important dimension, the positive power of the three theories rise and fall together.

Despite their tautological character, all three theories generated a groundswell of angry response because, if one imagined that their predictions survived the release of their perfect market assumptions, each theory attacked the value of important participants in the capital market. CAPM called into question the value of highly paid portfolio managers-simply assessing the volatility of an asset relative to that of the market might not command the same rewards as firm specific assessments of risk and reward. The Irrelevancy Propositions were even more offensive. Getting a corporation's debt-equity ratio right was a central function of chief financial officers (and their highly compensated investment banker consultants); why pay people large amounts to engage in an activity that does not increase the value of the firm? The ECMH took the attack one step further, calling into question not only the value of chartists (marginalized by weak form efficiency), but fundamental analysis as well (marginalized by semi-strong form efficiency).

While it is tempting to dismiss the reaction of capital market professionals as simply turf protection, that would miss the deeply felt belief that all three theories' perfect market elegance did not reflect the world in which the professionals worked. What happens when the theories confronted the real world where information was costly and asymmetrically distributed, at least some investors were plainly irrational, and transactions costs were pervasive?

Thus, the transformation of finance into financial economics gave rise to a set of theorems that explained the operation of asset pricing and capital structure in perfect capital markets and evoked a predictable reaction from those whose function the

14. Miller reports that even the tautological character of the propositions in a perfect capital market world was initially a difficult sell: "We first had to convince people (including ourselves!) that there could be any conditions, even in a 'frictionless' world, where a firm would be indifferent between issuing securities as different in legal status, investor risk and apparent cost as debt and equity." Id. at 100 (emphasis in original).

15. William F. Sharpe, Discussion, 25 J. FIN. 418, 418 (1970).

16. William H. Beaver, Market Efficiency, 56 ACCT. REV. 23, 32 (1981) (emphasis in original). 
theorems called into question. The next step, clear in hindsight but perhaps more murky at the time, was to find out the extent to which the real world capital market worked the way the financial economics predicted. ${ }^{17}$ This conflict-between the elegant world of perfect capital markets and the messy real world-defined the problem we addressed in MOME. We said that "[w]hat makes the ECMH non-trivial, of course, is its prediction that, even though information is not immediately and costlessly available to all participants, the market will act as if it were." 18 Thus, in MOME, we proposed "a general explanation for the elements that lead to-and limit-market efficiency." 19

\section{THE MOME THESIS}

Beginning in the $1980 \mathrm{~s}$, a growing empirical literature challenged the predictions of the 1960 s perfect market theorems, and in turn gave rise to a reassessment of the underlying theory. The Mechanisms of Market Efficiency was one such effort at explanation and reassessment. The principal focus of the MOME thesis was a concept that we termed "relative efficiency." By this we meant that particular information might be reflected in real-as opposed to ideal-market prices more or less rapidly (or, in our terminology, with more or less relative efficiency). The more quickly that prices reequilibrated to reflect new information, the more closely they behave "as if" they were set by the theorist's ideal of a market populated exclusively by fully-informed traders. Thus market efficiency, as we saw it, concerned how rapidly prices responded to information, rather than whether they responded "correctly" according to the predictions of a particular asset pricing model such as CAPM ${ }^{20}$ By the early $1980 \mathrm{~s}$, a large body of

17. The extent to which CAPM, the Irrelevance Propositions, and the ECMH were originally proffered as perfect market theorems with the goal of framing a research agenda that would relax the perfect market assumptions to the end of understanding how real markets work and how real institutions respond to market imperfections is an interesting question. Plainly the authors came to understand their work in that fashion. Looking back at his and Modigliani's early work with the benefit of thirty years of the efforts of others to show what market imperfections falsify the Irrelevance Propositions, Merton Miller acknowledges that "[l]ooking back now, perhaps we should have put more emphasis on the other, upbeat side of the 'nothing matters' coin: showing what doesn't matter can also show, by implication, what does." Miller, supra note 13, at 100 (emphasis in the original). Sharpe himself acknowledged in his Nobel lecture that CAPM is compromised when there are institutional restrictions on short-selling. William F. Sharpe, Capital Asset Prices With and Without Negative Holdings, $46 \mathrm{~J}$. FIN. 489 (1990). And one of the authors, roughly contemporaneously with MOME, framed the role of business lawyers as that of transaction cost engineers, whose task was to craft a transaction structure that allowed the parties to act as if CAPM's perfect market assumptions were really true. Ronald J. Gilson, Value Creation by Business Lawyers: Legal Skills and Asset Pricing, 94 YALE L.J. 239 (1984). This recognition of the value of perfect market theorems to understanding the messy real world surely will remind legal academics of the Coase theorem, Ronald Coase's seminal demonstration, which also formed the basis for the award of a Nobel Prize in Economics, that in a world without transaction costs, the allocation of liability is irrelevant. Ronald Coase, The Problem of Social Cost, 3 J.L. \& ECON. 1 (1960). There, however, Coase was explicit in his motivation: to demonstrate that precisely because the world was messy, the study of transaction costs should be the center of the scholarly agenda. Allen, supra note 4 , nicely makes this point.

18. Gilson \& Kraakman, supra note 1, at 552 (emphasis in original).

19. Id. at 553 .

20. Put another way, our view was that prices responded "correctly" to information to the extent that they responded rapidly. The only meaningful sense in which market prices can ever be said to be inefficient with respect to widely available information is that they have not yet responded fully-although they will sometime. As we discuss, supra note 4, we are skeptical of the utility of distinguishing between this concept of informational efficiency of price and "fundamental" efficiency. 
empirical work demonstrated that price responded extremely rapidly to most public and even "semi-public" information-too rapidly to permit arbitrage profits on most of this information. By and large, then, the public equities market appeared to be semi-strong form efficient, meaning that relative efficiency was high for public information. But how was this possible, given that most traders were likely to be uninformed about the content of much of this information?

We addressed this question on two levels. On the level of the capital markets, MOME proposed that four mechanisms work to incorporate information in market prices with progressively decreasing relative efficiency. First, market prices immediately reflect information that all traders know, simply because this information necessarily informs all trades, just as perfect markets theorists assumed ("universally-informed trading"). Second, information that is less widely known but nonetheless public, is incorporated into share prices almost as rapidly as information known to everyone through the trading of savvy professionals ("professionally-informed trading"). Third, inside information known to only a very few traders would find its way into prices more slowly, as uninformed traders learned about its content by observing tell-tale shifts in the activity of presumptively informed traders or unusual price and volume movements ("derivativelyinformed trading"). Finally, information known to no one might be reflected, albeit slowly and imperfectly, in share prices that aggregated the forecasts of numerous market participants with heterogeneous information ("uninformed trading"). ${ }^{21}$

In retrospect, the four market mechanisms that we introduced to sketch the institutional reality behind the rapid incorporation of public and semi-public information into share price seem stylized themselves. Subsequent research into the structure of trading markets reveals yet another level of micro-trading mechanisms at play in the channeling of information in prices, including the critical role played by market makers. ${ }^{22}$

Our concern, however, was not with the microstructure that underlies the mechanisms of market efficiency, but rather with the larger institutional framework of the market that regulated the distribution of information among traders, and hence determines which market mechanism incorporates information into price. Simply put, MOME's second claim was that cost determines the distribution of information in the market, and that this cost of information, in turn, depends on the market institutions that produce, verify, and analyze information-ranging from the Wall Street Journal to the exhaustive research of the best professional investors. While every step in the institutional pathways that channel information into price bears on the relative efficiency of market price, none are as important as the institutions that determine the transaction costs of acquiring and verifying information in the first instance.

21. Uninformed trading is the least efficient of the four market mechanisms, precisely because the true content of information is unknown and, as a result, price "averages" the partial information and opinion of all investors democratically. But this does not imply that we believed that market efficiency generally depends on the views of the average investor, as one writer in this volume seems to suggest. See Lynn Stout, The Mechanisms of Market Inefficiency: An Introduction to the New Finance, 28 J. CORP. L. 635 (2003). On the contrary, three of the four market mechanisms depend on the possession of information, and two are devices by which the views of informed traders enter price, even when these knowledgeable investors are a minority in the market.

22. See, e.g., Paul G. Mahoney, Market Microstructure and Market Efficiency, 28 J. CORP. L. 541 (2003). 


\section{The Challenge of BEHaVIORAL FinanCE}

In finance itself, the empirical literature challenging the perfect market theorems soon gave rise to a reassessment of the underlying theory. With respect to the Irrelevance Propositions, a focus on the imperfections in the market for information stimulated a series of explanations of how capital structure could matter if information was costly and asymmetrically distributed. If corporate managers had private information concerning the corporation's future prospects, and if bankruptcy is costly to managers, then exposing the corporation to a greater risk of bankruptcy either by paying dividends or maintaining a higher debt to equity ratio could credibly signal that information to the market and thereby influence the price of the corporation's securities. ${ }^{23}$ Correspondingly, capital structure could also function as an incentive: an increased risk of bankruptcy resulting from a more leveraged capital structure provides an incentive for managers, for whom bankruptcy would be costly, to work even harder. ${ }^{24}$

The Capital Asset Pricing Model always had problems when attention shifted from theory to empirical testing. First, it was not clear that CAPM could be tested at all. CAPM predicts a linear relationship between a stock's systematic risk and returns on the market portfolio. While the market portfolio is operationally defined as a securities index like the S\&P 500, the market portfolio theoretically consists of all investment assets, including non-tradable assets such as human capital. If the investigator cannot specify how the proxy for the market portfolio differs from the real but unobservable market portfolio, it is difficult to evaluate empirical results concerning how accurately CAPM predicts stock prices. Either a good prediction or a bad prediction may be the result of using an incomplete proxy for the market portfolio. A second problem arises out of the integrative role played by the ECMH. CAPM predicts how prices should be set. If observed prices are different from predicted prices, it could mean that CAPM is wrong, but it could also mean that the ECMH is wrong. ${ }^{25}$

Conceptual problems aside, the empirical results were not kind to CAPM. In the end, a security's beta does not predict its return very well. Two categories of evidence are especially relevant here. First, studies show that asset pricing models with multiple factors in addition to systematic risk do a better job of predicting prices. Fama and French, for example, find that they can better predict market prices with a three-factor pricing model that includes company size and book-to-market ratio in addition to systematic risk. ${ }^{26}$ More generally, the Arbitrage Pricing Model abandons the effort to determine nondiversifiable risk factors on the basis of a priori economic reasoning.

23. Bengt Holstrom \& Jean Tirole, The Theory of the Firm, in I HANDBOOK OF INDUSTRIAL ORGANIZATION 63 (Richard Schmalansee \& Robert Willig eds., 1989).

24. Interestingly, Michael Jensen himself draws on this literature to explain why the capital structure of LBO association portfolio companies is not irrelevant. See Michael Jensen, The Eclipse of the Public Corporation, HARV. Bus. Rev., Sept.-Oct. 1989, at 61.

25. See Richard Roll, A Critique of the Asset Pricing Theory's Tests, 4 J. Fin. ECON. 129, 130 (1977) (testing difficulties arising from incomplete proxy for market portfolio); Fama, supra note 12 (difficulties arising from joint testing of ECMH and CAPM).

26. Eugene F. Fama \& Kenneth R. French, Multifactor Explanations of Asset Pricing Anomalies, $51 \mathrm{~J}$. FIN. 55 (1996) [hereinafter Fama \& French, Anomalies]; Eugene F. Fama \& Kenneth R. French, Common Risk Factors in the Returns on Stocks and Bonds, 33 J. FIN. ECON. 3 (1993) [hereinafter Fama \& French, Risk Factors]. 
Instead, the APM specifies that prices are a linear function of factors derived from the data itself, which may include what appear to be measures of, perhaps, liquidity or inflation. ${ }^{27}$

Second, the CAPM's empirical failures appear to exhibit certain empirical regularities. The literature identifies a number of what are styled "anomalies," that is, persistent evidence of higher than predicted returns based on publicly available information. Consistent with the joint test problem, these results seem to be inconsistent both with CAPM and with the ECMH. Such anomalies include the tendency of small companies to earn higher than predicted returns; the seeming existence of a "January effect," in which much of the abnormal returns to smaller firms occurs during the first half of January; the "weekend effect," in which stock returns are predictably negative over weekends; and the "value effect," in which firms with high earnings-to-price ratios, high dividend yields, or high book-to-market ratios earn higher than predicted returns. ${ }^{28}$

A variety of explanations have been offered for the empirical discrepancies. Some explain the data as the result of incorrect asset pricing models. ${ }^{29}$ Others note that the studies revealing the anomalies are sensitive to the particular empirical techniques used, ${ }^{30}$ or demonstrate that at least some of the anomalies disappear or are dramatically reduced in size following their announcement in the literature, thus suggesting that markets learn, although not necessarily quickly. ${ }^{31}$

These more particularized problems with the link between perfect capital market theories and empirical reality have had their most significant impact, however, with respect to the ECMH. Here, in a movement called behavioral finance, an alliance of cognitive psychologists and financial economists have taken direct issue with the perfect market foundations of modern finance in general and the ECMH in particular. As discussed above, the core theories of modern finance assume that investors are fully rational (or that the market acts as if they are), and that markets are efficient and transactions costs small so that professionally-informed traders quickly notice and take advantage of mispricing, thereby driving prices back to their proper level. Behavioral finance takes issue with both these premises, arguing that many investors are not rational in their financial decision-making, that there are observable directional biases resulting from departures from rational decision-making, and that significant barriers prevent

27. See Stephen A. Ross, The Arbitrage Theory of Capital Asset Pricing, 13 J. ECON. THEORY 341 (1976) (advancing the arbitrage model of capital asset pricing)

28. For recent surveys of the empirical findings, see Nicholas Barberis \& Richard Thaler, A Survey of Behavioral Finance, in HANDBOOK OF THE ECONOMICS OF FINANCE (George Constantinides et al., 2003); G. William Schwert, Anomalies and Market Efficiency, in HANDBOOK OF THE ECONOMICS OF FINANCE (George Constantinides et al. eds., 2003).

29. Suppose that it is difficult to diversify one's human capital and that human capital is especially sensitve to economic downturns, so that individuals bear an undiversifiable risk. Investors then will desire to hold more financial assets that fare better in bad times, for which value oriented characteristics are a proxy. See Fama \& French, Anomalies, supra note 26; Fama \& French, Risk Factors, supra note 26; John H. Cochrane, New Facts in Finance, in HANDBOOK OF THE ECONOMICS OF FINANCE (George Constantinides et al. eds., 2003). (1998).

30. Eugene Fama, Market Efficiency, Long-Term Returns, and Behavioral Finance, 49 J. FIN. ECON. 283

31. See, e.g., Schwert, supra note 28; Mark Rubenstein, Rational Markets: Yes or No? The Affirmative Case, FIN. ANALYSTS J., May-June 2001, at 15. Consistent with the sources cited in note 25, supra, an alternative interpretation of these results is that CAPM is simply untestable. 
professional traders from fully correcting the mistakes made by less than rational investors. ${ }^{32}$

The criticism of the rationality premise builds on an important literature growing out of work by cognitive psychologists Daniel Kahneman and Amos Tversky, which uses decision-making experiments to show how individuals' cognitive biases can lead them to systematically misassess an asset's value. ${ }^{33}$ The list of biases has grown impressively with time, and includes overconfidence, the tendency of individuals to overestimate their skills; the endowment effect, the tendency of individuals to insist on a higher price to sell something they already own than to buy the same item if they do not already own it; loss aversion, the tendency for people to be risk averse for profit opportunities, but willing to gamble to avoid a loss; anchoring, the tendency for people to make decisions based on an initial estimate that is later adjusted, but not sufficiently to eliminate the influence of the initial estimate; framing, the tendency of people to make different choices based on how the decision is framed such as whether it is framed in terms of the likelihood of a good outcome or in terms of the reciprocal likelihood of a bad outcome; and hindsight, the tendency of people to read the present into assessments of the past. ${ }^{34}$

Individuals whose decisions are subject to one or more of these biases, referred to in the literature as "noise traders," will then make investment decisions that deviate from those that theory would predict of rational investors. Lee, Shliefer, and Thaler's clever effort to explain the discount often associated with closed-end mutual funds, one of the long-standing phenomena that conflicts with the $\mathrm{ECMH}$, aptly illustrates the potential for such misguided investors to influence price efficiency. ${ }^{35}$ When an investor sells shares in

32. Among a large number of surveys by economists, see ANDREI SHLEIFER, INEFFICIENT MARKETS: AN INTRODUCTION TO BEHAVIORAL FINANCE (2000); and Barberis \& Thaler, supra note 28. Among legal commentators, see Donald C. Langevoort, Taming the Animal Spirits of the Stock Market: A Behavioral Approach to Securities Regulation, 97 Nw. U. L. Rev. 135 (2002), for a careful discussion. Cunningham, supra note 7 , presents the behavioral case more aggressively. Note that it is not only irrational biases that can contribute to "noisy" trading; incomplete markets might induce rational but informationless trading that distorts the information content of share prices. We are grateful to Allen Ferrell for calling this point to our attention.

33. For a collection of their early work, see JUDGMENT UNDER UNCERTAINTY: HEURISTICS AND BIASES (Daniel Kahneman, Paul Slovic \& Amos Tversky eds., 1982). Thaler \& Barberis, supra note 28; and David Hirschliefer, Investor Psychology and Asset Pricing, 56 J. FIN. 1533 (2001), provide recent finance oriented surveys. Daniel Kahneman's receipt of the 2002 Nobel Prize in Economics for this body of work is dramatic evidence of these psychologists' impact on economics. Because of his untimely death, Amos Tversky was not eligible to share in the Nobel Prize award. The symposium, Empirical Legal Realism: A New Social Scientific Assessment of Law and Human Behavior, 97 Nw. U. L. Rev. 1075 (2003), considers the impact of the literature on a variety of matters of legal concern.

34. The hindsight bias is our current favorite example. In 2002, Lawrence Cunningham described the state of the ECMH literature in the mid-1980s: "Among the legal scholars, the EMH became so dominant that two leading corporate law teachers [Gilson and Kraakman] announced that it was the context in which to discuss markets ...." Cunningham, supra note 7, at 773 (emphasis in the original). When we first presented MOME at the symposium in connection with which it was published, Gilson had been teaching for four years, Kraakman for three. We self-servingly choose to interpret the comment as hindsight bias.

35. Charles Lee, Andrei Shleifer, \& Richard Thaler, Investor Sentiment and the Closed-End Fund Puzzle, 46 J. FIN. 75 (1991). We note that the econometrics in this article gave rise to a heated debate. See Nai-Fu Chen, Raymond Kan \& Merton Miller, Are the Discounts on Closed-End Funds a Sentiment Index?, 48 J. FIN. 795 (1993) (discounting Lee et al.'s attempt to solve the discounts on the closed-end funds puzzle); Navin Chopra, Charles M.C. Lee, Andrei Shleifer \& Richard Thaler, Yes, Discounts on Closed-End Funds Are a Sentiment Index, 48 J. FIN. 801 (1993) (supporting their earlier paper over Chen et al.'s criticism); Nai-Fu Chen, Raymond 
a closed-end mutual fund, she receives whatever a buyer is willing to pay, rather than a proportionate share of the fund's net asset value, as she would if she redeemed her interest in an open-end mutual fund. Because the net assets of a closed-end fund are observable, the ECMH predicts that the stock price of a closed-end fund should reflect its net asset value. In fact, closed-end funds systematically (but not uniformly) trade at a discount from their underlying asset value, a serious problem for the claim that stock prices generally are the best estimate of a security's value. In the one case where we can actually observe underlying asset value, stock price diverges from it. ${ }^{36}$

Lee, Shleifer, and Thaler blame this phenomenon on noise traders, whose views about value, perhaps because of some combination of the litany of cognitive biases, plainly ignore the value in their primary market of the securities held by the closed-end fund. Using individual, non-professional investors as a proxy for noise traders-should we all take this personally? - the authors note that institutions hold only a very small percentage of closed-end mutual fund shares, leaving individual investors as the central clientele for this type of investment.

Importantly, however, the presence of noise traders alone is insufficient to result in inefficient market prices. Two other elements are necessary. First, the biases held by the noise traders must be more or less consistent; otherwise, at least some of the biases will, in effect, regress out. ${ }^{37}$ Second, arbitrageurs must be unwilling to police the resulting price inaccuracies. Under perfect capital market assumptions, fully informed traders with unlimited access to capital immediately pounce on mispriced securities. If arbitrageurs were available to trade against the noise traders, then their action would suffice to return prices to their efficient level. In the case of closed-end mutual funds, however, the absence of institutional investors in this niche limits the extent of corrective arbitrage, and prices retain an irrationality component.

This limited arbitrage condition is critical to the behavioral finance perspective, ${ }^{38}$ and the problem is more general than the simple case of closed-end mutual funds. Limits on arbitrage fall into four general categories: fundamental risk; noise trader risk; institutional limits, both regulatory and incentive; and the potential that even professional traders may be subject to cognitive biases.

The problem of fundamental risk simply reflects the fact that, unless hedged, the arbitrageur has a position in the stock of a particular company that is exposed to loss from a change in that company's fortunes. This can be avoided by holding an offsetting position in a substitute security. However, substitutes may not be available and in all

Kan \& Merton Miller, Yes, Discounts on Closed-End Funds are a Sentiment Index: A Rejoinder, 48 J. FiN. 890 (1993) (reaffirming their point that Lee et al.'s sentiment index does not work). Recent analysis of UK closed end funds suggests that the amount of noise trading does not explain the size of discounts on particular funds, but that variations in retail investor demands for funds-a different index of small investor sentiment-does explain changes in aggregate fund discounts over time. See Gordon Gennill \& Dylan C. Thomas, Noise Trading, Costly Arbitrage, and Asset Prices: Evidence from Closed-End Funds, 57 J. FIN. 2571 (2002).

36. Reinier Kraakman, Taking Discounts Seriously: The Implications of "Discounted" Share Prices as an Acquisition Motive, 88 COLUM. L. REv. 891 (1988).

37. Andrei Shleifer and Lawrence Summers acknowledge this condition: "These demand shifts [trading resulting from noise traders' irrational views] will only matter if they are correlated across noise traders. If all investors trade randomly, their trades cancel out ...." Andrei Shleifer \& Lawrence Summers, The Noise Trader Approach to Finance, 4 J. EcoN. PersP. 19, 23 (Spring 1990).

38. See, e.g., Shleifer \& Summers, supra note 37 , at 24 (stressing limitations on arbitrage). 
events will be imperfect. Barberis and Thaler offer the illustration of an arbitrageur who believes that Ford is underpriced. To hedge the risk associated with purchasing Ford, the arbitrageur simultaneously shorts GM. But this strategy only provides a hedge against bad news in the automobile industry generally; it does not hedge against firm-specific bad news about Ford ${ }^{39}$ (and to the extent that bad news for Ford is good news for GM, it may actually increase firm-specific risk). The arbitrageur must therefore expect a higher return to offset her basis risk, which in turn reduces arbitrage activity and lowers market efficiency. The result is much like Grossman and Stiglitz's now familiar point that informationally efficient markets are impossible because full efficiency eliminates the returns to the very activity that makes the market efficient, with the result of an "equilibrium degree of disequilibrium." 40

The impact of noise trader risk on arbitrage effectiveness reflects the same mechanism as operative with respect to fundamental risk but differs in the mechanism's trigger. With respect to fundamental risk, the arbitrageur must be compensated for the risk that she will have accurately estimated the probability distribution concerning future economic performance, but that the ultimate realization turns out unfavorable to her position. With respect to noise trader risk, the uncertainty concerns neither the accuracy of the arbitrageur's analysis, nor even the realization. In addition to this fundamental risk, the arbitrageur also bears the risk that noise traders will continue to be irrational, therefore maintaining, or even increasing, the mispricing. Since the arbitrageur will also have to be compensated for the risk that noise traders continued confusion will adversely affect the value of their rational bets, the required return goes up and level of activity goes down, resulting in a cost driven level of market inefficiency. ${ }^{41}$

Institutional limits on arbitrage reflect barriers to arbitrageurs trading away information inefficiencies that result not from market risk, but from the structure of the institutions through which the arbitrageurs act. For our purposes, these limits fall into two categories: regulatory and market constraints on the mechanisms of arbitrage, and the structure of arbitrageurs' incentives. Each category operates to restrict the extent to which arbitrage can correct mispricing.

Regulatory restrictions on arbitrage are directed at short-sales, undertaken by an arbitrageur when she believes the market price of a security is higher than its efficient price. In a short sale, the arbitrageur sells a security she does not own. To accomplish this, she must first find an existing owner of the overpriced security who is willing to lend the security to the arbitrageur. The borrowed stock is then sold, the arbitrageur betting that the price of the security will fall before the security must be purchased to repay the loan. ${ }^{42}$

Securities Exchange Act Rules 10a-1 and 10a-2 provide the basic regulatory framework. Rule 10a-1, the "uptick test," generally prohibits a short sale at a price below

39. Barberis \& Thaler, supra note 28 .

40. Sanford J. Grossman \& Joseph E. Stiglitz, On the Impossibility of Informationally Efficient Markets, 70 AM. ECON. REV. 393, 393 (1980).

41. See J. Bradford DeLong, Andrei Shleifer, Lawrence Summers \& Robert Waldman, Noise Trader Risk in Financial Markets, 98 J. POL. ECON. 703 (1990); Shleifer \& Summers, supra note 37.

42. Securities Exchange Act of 1934 Rule 3b-3 defines a short sale as any sale of a security that the seller either does not own or is closed by delivery of a borrowed security. For a transactional account of the steps in a short-sale, see Gene D'Avolio, The Market for Borrowing Stock, 66 J. FIN. ECoN. 271 (2002) 
the security's last reported price, and Rule 10a-2 restricts activities by broker-dealers that could facilitate a violation of the uptick rule. ${ }^{43}$ The idea behind the prohibitions, dating to the aftermath of the stock market crash of 1929, is to prevent "speculators" from driving down the price of a stock by continuing to sell stock below the market price. ${ }^{44}$ The difficulty with the rule is simply the obverse of its asserted benefit. Short-selling, through its information revealing properties, pushes stock prices to a lower, more efficient level; to the extent that the uptick rule actually succeeds in restricting arbitrage, the level of market efficiency suffers. ${ }^{45}$

Market restrictions on short-selling involve both limits on the demand side-the parties who can engage in short selling-and on the supply side-the costs and availability of shares to borrow to affect a short sale. While the Securities Exchange Act 316(c) restricts short-selling by officers, directors, and large shareholders of publicly traded companies, the more serious demand constraint is voluntary; a recent SEC study reports that only some $43 \%$ of mutual funds were authorized by their charters to sell short. ${ }^{46}$ During the six-month period ending April 30, 2003, only approximately $2.5 \%$ of registered investment companies (236 out of some 9000) actually engaged in shortselling. ${ }^{47}$ Because $79 \%$ of mutual funds report that they do not use derivatives, ${ }^{48}$ it is unlikely that the charter restrictions are being avoided through the use of synthetic securities. ${ }^{49}$

Market restrictions on the supply side relate to the lending market for the securities that must be borrowed for a short sale to be made. Preparation for a short sale begins with a request that the arbitrageur's broker find a lender for the shares that are to be sold. The universe for potential lenders include the broker itself if it has an inventory of the desired stock, or institutional investors, including pension funds, insurance companies, and index

43. More fully stated, an exchange listed security may be sold short only (1) at a price above the immediately preceding reported price ("plus tick"), or (2) at the last sale price if it is higher than the last different reported price ("zero-plus tick"). For NASDAQ listed securities, NASD Rule 3350 prohibits NASD members from effecting short-sales when the best bid displayed is below the preceding best bid for the security. See Implications of the Growth of Hedge Funds, Staff Report to the United States Securities and Exchange Commission 41 (Sept. 29, 2003) [hereinafter SEC Hedge Fund Study]; Jonathan R. Macey, Mark Mitchell \& Jeffrey Netter, Restrictions on Short Sales: An Analysis of the Uptick Rule and its Role in View of the October 1987 Stock Market Crash, 74 CORNELl L. REV. 799 (1989).

44. Macey et. al, supra note 43.

45. Michael Powers, David Schizer \& Martin Shubik, Market Bubbles and Wasteful Avoidance: Tax and Regulatory Constraints on Short Sales, n.35, 40 (Working Paper, March 2003), available at http://ssm.com/ abstract $=39102$ (last visited Nov. 1, 2003), collect the substantial body of literature showing that restrictions on short-sales inflate prices. The authors also point out that the tax law imposes an additional cost on short-selling by effectively denying profits from a short position the more favorable capital gains rate accorded profits from long positions. On October 22, 2003, the SEC proposed for comments a new Regulation SHO that would modernize and replace Rules $10 \mathrm{a}-1$ and $10 \mathrm{a}-2$. In addition to substantially reducing the bite of the uptick rule, the new regulation would adopt a pilot program that authorizes the SEC to choose 300 of the 1000 largest U.S. stocks for which restrictions on short-selling would be suspended for two years, following which the performance and volatility of these shares would be compared to that of stocks subject to the new regulation.

46. SEC Hedge Fund Study, supra note 43, at 108.

47. Id.

48. Jennifer L. Koski \& Jeffrey Pontiff, How are Derivatives Used? Evidence from the Mutual Fund Industry, 54 J. FIN. 791 (1999).

49. Joseph Chen, Harrison Hong \& Jeremy Stein, Breadth of Ownership and Stock Returns, 66 J. FIN. ECON. 171, 172 (2002). 
funds, all of whom have long-term strategies that are unlikely to be negatively affected by liquidity constraints resulting from securities lending. The arbitrageur transfers collateral to the lender in the amount of $102 \%$ of the value of the borrowed securities, typically in cash. The lender then pays interest to the arbitrageur on the cash collateral, termed the rebate rate, and has the right to call the loan at any time. If the loan is called at a time when the shares have risen in value, the arbitrageur will be forced to close her position at a loss unless another lender is found. Additionally, SEC Regulation T requires that the arbitrageur post a margin of $50 \%$ of the borrowed securities' value in additional collateral.

In general, the lending market available to short sellers for large issuer securities is broad and deep. Large cap stocks are generally easy and cheap to borrow, with the great majority requiring loan fees of less than $1 \%$ per year. ${ }^{50}$ In contrast, borrowing smaller cap stocks with little institutional ownership may be difficult and expensive. ${ }^{51}$ As many as $16 \%$ of the stocks in the Center for Research in Security Prices file may be impossible to borrow. These companies are quite small, in total accounting for less than $1 \%$ of the market by value, with most being in the bottom decile by size and typically trading at under $\$ 5.00 .52$

Recent theoretical and empirical work suggests that it is more costly to borrow a stock the greater the divergence of opinion in the security's value. The logic reflects the fact that those who do not lend the security forego the price they would have received for its loan. Thus, those holding a stock must value it more highly than those who lend it by an amount in excess of the loan fee. The greater the divergence of opinion concerning the stock's value, the higher the loan fees, yielding the perverse result that the transaction costs of arbitrage increase in precisely the circumstance when the activity is most important. ${ }^{53}$

Consistent with significant market limits on arbitrage, short interest in securities is generally quite small. A recent study reports that over the period 1976 through 1993, more than $80 \%$ of listed firms had short interests of less than $0.5 \%$ of outstanding shares, and more than $98 \%$ had short interests of less than $5 \%, 54$ a level consistent in magnitude with earlier assessments. ${ }^{55}$ And consistent with a significant impact on market efficiency from limited arbitrage, the empirical evidence "is broadly consistent with the idea that short-sales constraints matter for equilibrium stock prices and expected returns." 56 The problem, however, is with the magnitude of the costs. If the stock of all but small, noninstitutional stock is readily available for borrowing, the regulatory and market imposed

50. D'Avolio, supra note 42, at 273.

51. The discussion in the text is based on accounts of the short sale process in Charles M. Jones \& Owen A. Lamont, Short-sale Constraints and Stock Returns, 66 J. FIN. ECON. 207 (2002); Christopher C. Geczy, David A. Musto \& Adam V. Reed, Stocks are Special Too: An Analysis of the Equity Lending Market, $66 \mathrm{~J}$. FIN. ECON. 241 (2002); Darrell Duffie, Nicole Gârleanu \& Lasse Heje Pedersen, Securities Lending, Shorting, and Pricing, 66 J. FIN. ECON. 307 (2002).

52. D'Avolio, supra note 42, at 273.

53. Chen et al., supra note 49 and D'Avolio, supra note 42, present empirical evidence and a review of the literature.

54. Patricia M. Dechow, Amy P. Hutton, Lisa Meulbroek \& Richard G. Sloan, Short-Sellers, Fundamental Analysis, and Stock Returns, 61 J. FIN. ECON. 77 (2001).

55. See Jones \& Lamont, supra note 51, at 212.

56. Chen et al., supra note 49 , at 201. 
transaction costs of short-selling seem too small to account for the limited amount of short-selling we observe and for its impact on pricing. A recent study of the impact of short-selling constraints concluded that

An interesting question that our work raises, but does not answer, is this: why do short-sale constraints seem to be so strongly binding? Or said slightly differently: why, in spite of the high apparent risk-adjusted returns to strategies involving shorting, is there so little aggregate short interest in virtually all stocks? ... [W] [ are skeptical that all, or even most of the answer has to do with ... specific transaction costs. 57

The structure of arbitrageurs' incentives may provide the identity of the dark matter of the short sale universe - the source of constraints that the transaction costs of short selling do not explain. Recent work highlights a number of incentive problems, including a more realistic account of arbitrageurs' goals and the agency costs of arbitrage.

The first problem is that we have, to this point, operated on a quite naïve framing of the goal of arbitrageurs. In effect, we have treated arbitrageurs as a kind of market-maker whose role is to police the efficiency of prices and whose efforts will be compromised to the extent that regulatory and transaction costs make short-selling costly. In fact, however, arbitrageurs have a quite different goal: to make money. This, in turn, suggests that arbitrageurs act not only on a difference between a stock's market price and its fundamental value, but also on a difference between a stock's current market price and its future market price, regardless of the relation between its future market price and its fundamental value. Here the idea is simply that if overly optimistic noise traders are in the market, shorting the stock is not the only way to make money. Instead, one can profit by anticipating the direction of the noise traders' valuation error, and taking advantage of that error through long, not short, positions with the goal of selling the shares to noise traders at a higher future price. The result may be to drive up the price of already overvalued stocks, and to prolong the length and increase the extent of bubbles. ${ }^{58}$

The second problem is the agency costs of arbitrage, arising from, as Andrei Shleifer has nicely put it, the fact that "brains and resources are separated by an agency relationship." 59 To see this, keep in mind that arbitrage positions are made based on ex ante expectations, but the gain realized depends on ex post outcomes. The two may differ because of either the arbitrageur's skill in identifying mispricing or because of fundamental or noise trader risk; that is, an investment may fail either because of bad judgment or because of bad luck.

57. Id. at 201 (emphasis in original). D'Avolio reaches a similar conclusion:

While specialness [high loan fees] and recall risk could be onerous for many mid- to small-sized stocks, they cannot explain low short interest among S\&P 500 stocks. To fully understand the observed reluctance, researchers must explore less explicit measures of short seller costs and risksones that extend beyond the loan market.

D'Avolio, supra note 42, at 303.

58. See, e.g., J. Bradford DeLong, Andrei Shleifer, Lawrence Summers \& Robert Waldman, Positive Feedback Investment Strategies and Destabilizing Rational Speculation, 45 J. FIN. 379 (1990) (discussing the possibility that noise traders follow positive feedback strategies-buy high, sell low); Jeremy Bulow \& Paul D. Klemperer, Rational Frenzies and Crashes, 112 J. POL. ECON. 1 (1994) (arguing that because buyers can choose when to buy, markets are extremely sensitive to new information); SHLEIFER, supra note 6, ch. 6.

59. SHLEIFER, supra note 6, at 89. 
For an arbitrageur trading for her own account, we can presume the explanation for a failed investment is observable. But now assume that the arbitrageur is instead an investment professional whose capital is raised from institutional investors and who receives a portion of the profits-the arbitrageur runs a hedge fund. Because the initial ex ante assessment of the portfolio investment is not observable to the fund investor, the investor then may use the investment's ex post outcome as a proxy of the arbitrageur's skill, with the effect of exposing the arbitrageur's human capital to both fundamental and noise trader risk because the fund investor may mistakenly treat a loss that really results from bad luck as evidence of bad judgment. Arbitrageurs thought to have "bad judgment" will have difficulty raising new funds. This potential, in turn, will cause the arbitrageur to reduce her risk by taking more conservative positions. Importantly, the personal risk to the arbitrageur increases as the importance of arbitrage as a means to correct market price increases. The greater the disagreement about a stock's price, the greater the bad luck risk that the arbitrage position turns out badly and, hence, the greater risk to the arbitrageur's human capital. ${ }^{60}$

This interaction between noise trader risk and the agency costs of arbitrage can plausibly lead to bubble-like conditions. Once noise traders enter the market in large numbers, the risk to arbitrage increases, which in turn results in an independent reduction in the level of arbitrage. This reduction, one might imagine, is more or less linear. More important, the presence of a market driven by noise traders has the potential to create a kink in the arbitrage supply curve, when the potential profits from momentum trading exceeds the potential profit from short-selling. From this perspective and extrapolating from Lee, Shleifer, and Charles' treatment of closed end mutual funds, one might consider a sharp increase in the number of individual investors in the market as a pre-bust signal of a bubble. This assessment turns on its head the familiar anecdotal observation that when individuals get into the market the professionals get out: when individuals enter the market in large numbers, professionals find something to sell them.

A final potential limit on arbitrage looks back to the psychological biases that may underlie the noise trader phenomenon. To this point, we have treated arbitrageurs as if they still met the perfect rationality assumption of traditional theory-even if they are responding to the presence of noise traders or frictions in the incentive structure they face, they do so rationally. In the end, however, even professional traders are people. Maybe they are subject to cognitive biases as well; that is, the existence of irrational professional traders may be a limit to arbitrage.

The issue whether some or all of the cognitive biases are hard wired or can be diminished by education or experience is a contested subject whose review is far beyond our ambition here. For present purposes, we note only that when the studies place individuals in a position where the goal is to make money, the cognitive biases seem to

60. This approach is that of Andrei Shleifer \& Robert Vishny, The Limits of Arbitrage, 52 J. FiN. 35 (1997). In structure, the agency model should be familiar. In a somewhat different form, it has provided the economic basis for the business judgment rule: because courts and juries will find it difficult to distinguish between director decisions that result in bad outcomes because of bad judgment or because of bad luck, imposing liability on directors will result in conservatism to avoid the cost of the legal system making a mistake in assessing causation. See also RONALD J. GILSON, THE LAW AND FINANCE OF CORPORATE ACQUISITIONS 866-68 (1986) (arguing lawyers provide too conservative advice when clients use bad outcomes as a proxy for bad judgment). 
disappear quickly. ${ }^{61}$ And because the organization has the capacity to shape the traders' incentives so that the goal is clear, the potential for learning to occur and be reinforced is significant. Thus, for our purposes, we will treat professional traders as rational actors in responding to the incentives that they face.

\section{A Tentative Assessment of the Behavioral Finance Principles}

Assessing the contribution of behavioral finance to the market efficiency debate even on the tentative basis we have in mind here, as well as avoiding some of the shrillness that has been associated with the debate, requires that we be quite clear both about the aspect of market efficiency we have in mind, and which of the two behavioral finance principles-investor irrationality and limits on arbitrage-is doing the heavy lifting. From our perspective, evidence that some investors sometimes systematically deviate from rational decision-making is not a revelation. Roughly coincident with the publication of MOME, one of us published a text on the Law and Finance of Corporate Acquisitions that contained a lengthy excerpt from a survey article by Amos Tversky and Daniel Kahneman, to our knowledge the first time their work appeared in corporate law teaching materials. ${ }^{62}$ What makes the market efficiency claim non-trivial is that prices are said to be efficient despite the fact that perfect market assumptions do not hold. Investor irrationality on the part of some investors, like information costs and transaction costs, affects relative efficiency. Irrationality takes on special meaning only if its impact on the incorporation of information into price differs from that of other market imperfections. Otherwise, limits on arbitrage should command the most attention (including, of course, those limits that are linked to investor irrationality).

\section{A. The Investor Irrationality Principle}

Despite the body of experimental evidence supporting persistent decision-making biases in some portion of the population, we are skeptical that this phenomenon will be found, generally, to play a significant role in setting aggregate price levels. Start with the familiar complaint that the sheer number of biases that have been identified, together with the absence of precision about which bias, or combination of biases, are operative in particular circumstances, leaves too many degrees of freedom in assigning causation. For example, the psychology literature has been proffered to support giving a target board of directors more discretion to undertake defensive action-cognitive biases may cause the

61. In a helpful and balanced assessment of the literature, Mark Kelman notes:

[V]iolations of rationality precepts seem to disappear rather quickly when people have the opportunity to make decisions again. [Especially] ... when those who will have the chance to repeat the decisionmaking process are rewarded if they behave the way rational choice theorists believe the normative decisionmaker should behave, and are penalized if they do not.

Mark Kelman, Law and Behavioral Science: Conceptual Overviews, 97 Nw. U. L. REv. 1347, 1380 (2003). See also John A. List, Does Market Experience Eliminate Market Anomalies, 118 Q.J. ECON. 41 (2003) (providing experimental evidence that experience significantly eliminates the endowment effect).

62. Ronald J. Gilson, The LAW AND FInANCE OF CoRPORATE ACQUisitions 99-112 (1986) (excerpting Amos Tversky \& Daniel Kahneman, Judgment Under Uncertainty: Heuristics and Biases, 185 SCIENCE 1124 (1974)). 
shareholders to make the wrong decision. ${ }^{63}$ But what bias can be predicted to operate in this setting? If one imagines the endowment effect is at work on target shareholders, then they may require too high a price for their stock, and mistakenly let a good offer pass. Alternatively, if one imagines that the shareholders are loss averse, and if they anchor the measure of their loss by the premium offered, they may fear the risk of losing the existing premium more than they value the chance of a still higher offer. ${ }^{64}$ One cannot help but be reminded of Karl Llewellyn's famous demonstration that for every canon of statutory interpretation there is an equal and opposite canon, leaving one in search of a meta principle that dictates when one or the other applies. ${ }^{65}$

Indeed, this indeterminacy concerning the incidence and interaction of the variety of cognitive biases raises the possibility that biases could not be shown to influence aggregate price levels even if they did. Here the concern echoes that raised by Richard Roll with respect to testing CAPM-if one cannot observe the market portfolio, one cannot assess the extent to which one's proxy differs from it. ${ }^{66}$ If one cannot observe which biases are operative and their interaction, one may not be able to assess whether a market price reflects any bias at all.

To be sure, the indeterminacy criticism is overstated in the sense that it applies the ambitions of economics to cognitive psychology. It is unlikely that this body of work will lead to models like arbitrage pricing, which would aspire to estimate what biases apply in particular circumstances and their coefficient-the weight each bias has in the ultimate decision. As Mark Kelman stated recently:

[T]he fact that one recognizes the existence of hindsight bias may make it somewhat more plausible that decision makers are not perfectly rational in general or, a touch more narrowly, in assessing the probability of events. However, its existence does not make it any more likely that they are subject to any of the other particular infirmities of reasoning ... that behavioral researchers have identified. ${ }^{67}$ But the fact that a vice does not quite close does not mean it is without value in addressing more general, as opposed to more

63. Martin Lipton \& Paul Rowe, Pills, Polls and Professors: A Reply to Professor Gilson, 27 J. CoRP. L. 1 (2002). Perhaps this is what the Delaware Supreme Court means by substantive coercion.

64. Of course, this framing of the problem depends on when the shareholders switch their reference point from the market price to the offered price. This quandary has real world importance. Those who backpack in the Sierra Nevada mountains know that black bears suffer from the endowment effect. The park rangers' standard advice about what to do when a bear enters your camp looking for food is to throw stones at it, bang pans, and otherwise aggressively seek to chase the bear away. That advice changes, however, if the bear actually gets your food. At that point, the food instantly becomes part of the bear's endowment, and one can be hurt trying to take the food away. For those of us who are somewhat skittish about large animals with sharp teeth, the precise point when the endowment effect kicks in and triggers the possibility of violently expressed loss aversion is awfully important.

65. Karl N. Llewellyn, Remarks on the Theory of Appellate Decision and the Rules or Canons About How Statutes are to be Construed, 3 VAND. L. REV. 395 (1950). This type of indeterminacy or "degrees of freedom" criticism is voiced in Jeffrey Zwiebel, Review of Shleifer's Inefficient Markets, 40 J. ECON. LIT. 1215 (2002). To some extent, the "equal and opposite" criticism is exaggerated. Take two familiar and competing homilies"the early bird gets the worm" and "look before you leap." If each is plainly dominant in a particular domain (and hence their status as a homily), the indeterminancy problem concerns only the areas where the two domains overlap.

66. Roll, supra note 25.

67. Kelman, supra note 61 , at 1350. 
precise, problems. ${ }^{68}$

For the purpose of evaluating the role of irrationality in setting prices, however, this criticism is important. It means that the simple presence of cognitive biases has no necessary implications for prices at all. Indeed, we cannot dismiss the possibility that the price effects of offsetting biases, on a single individual or across individuals, regress out in significant respect and thereby reduce the pressure on arbitrage, that is, on the mechanisms of market efficiency.

The same analysis also suggests circumstances where investor irrationality should be a matter of real concern. When a single bias extends across most noise traders, the price effect will not regress out, leaving a much heavier burden on arbitrage. And the problem will increase more than monotonically as the number of infected noise traders increases. As the volume of irrational trades increases, a point is reached where the arbitrageur's most profitable strategy shifts from betting against the noise traders to buying in front of them, with the goal of exploiting the noise traders mistake by selling them overvalued stock. In other words, increasing numbers of similarly mistaken noise traders serves to turbo-charge the price impact of their mistake. A sharp increase in the participation of individual investors is a powerful indication that they share a common bias-the likelihood that a coincidence of different biases all lead to increasing participation at the same time seems small. Thus, a spike in individual trading, Lee, Shleifer, and Thaler's proxy for noise trading, may serve as a limited predictor of price bubbles.

Where do we come out, then? Very tentatively, we suggest that noise trading-or investor irrationality-is likely to matter to price episodically. Under conditions of "normal trading," the arbitrage mechanism will suffice to cabin the eddies of bias in noise trading, and the extent to which irrationality influences price will be set by other constraints on arbitrage including transaction costs and the costs of information. However, circumstances of abnormal trading-when a spike in the number of individual investors suggests that noise traders will share a common mistaken belief-will give rise to a shift in arbitrageur strategy that drives prices further from efficiency. On these occasions, arbitrage constraints on price are relaxed, and the effects of cognitive biases on prices are likely to be of significantly greater magnitude than cost-based deviations from perfect market conditions.

Thus, our attention will focus on arbitrage limits in assessing the impact of behavioral finance on the market efficiency debate. However, this emphasis does not mean that the bias literature does not usefully speak to matters of financial market concern. Rather, we expect that it will have its greatest impact on circumstances when the concern is not with aggregate price effects, but with the behavior of individual investors. As we will discuss in more detail in Part VI, we may care a great deal if individuals systematically make poor investment decisions with respect to their retirement savings, especially with the growing shift from defined benefit to defined contribution pension plans, even if their mistakes do not affect price levels at all. Put differently, we may care what happens to the people whose mistakes are regressed out.

68. It is important to stress that the fact that research in cognitive psychology does not solve problems in economics is no criticism of psychology literature. Interdisciplinary scholarship encounters its own "limits on arbitrage"-other disciplines have their own agendas as the overlap between disciplinary areas of interest is only partial. 


\section{B. Limits on Arbitrage}

In contrast to our skepticism that cognitive biases will have a significant influence on relative market efficiency other than episodically (when the number of individual investors spikes and their biases therefore likely coincide), we are quite sympathetic to concerns that agency and incentive problems constrain the professionally-informed trading mechanism continuously, even in times of normal trading. MOME's relative efficiency concept, following Grossman \& Stiglitz, builds on the idea that the cost of information limits the effectiveness of professionally-informed trading-it has to pay to be informed. Agency and incentive problems between, for example, hedge funds and their investors and between hedge funds and their portfolio managers, pose the same kind of tradeoff-it has to pay to reduce these costs. ${ }^{69}$

That said, the recent literature identifying the limits on arbitrage ${ }^{70}$ closes a fascinating circle of intellectual history. As we described in Part I, the late 1950s and early 1960s gave rise to a wave of models that described the workings of segments of the capital market under perfect market conditions: asset prices were a function only of systematic risk; capital structure did not affect firm value; and informationally efficient markets policed these relationships through arbitrage. Almost from the beginning, the Irrelevancy Propositions were attacked for the extent to which their assumptions differed from the observed world, and for the fact that observed capital structures displayed regularities. The parallel rise of agency and information economics then provided a conceptual structure to order how deviations from perfect market assumptions rippled through corporate finance. The limits on arbitrage literature extend this project to the joined-at-the-hip subjects of asset pricing and market efficiency. The circle closes.

But why all the fanfare? Precisely because it does not depend on the presence of cognitive biases, the limits on arbitrage literature seem to be very useful, but entirely straightforward steps in the project of moving from a perfect market extreme null hypothesis to the messy world where transaction costs are positive, agents are disloyal, and information is costly and unevenly distributed. ${ }^{71}$ We thought we had signed on to

69. Models of herd behavior, for example, reflect this phenomenon. See, e.g., Jeffrey Zwiebel, Corporate Conservatism and Relative Compensation, 103 J. POL. ECON. 1 (1995) (demonstrating how outside concerns may deter managers from taking innovative actions); David Scharfstein \& Jeremy Stein, Herd Behavior and Investment, 80 AM. ECON. REV. 465 (1990) (examining forces that can lead to herd behavior). Michael Klausner has suggested that agency limits on arbitrage might temper our view with respect to the uptick rule, see supra text accompanying note 43 , because such limits could lead to mispricing short of the large, sharp price movements associated with crashes and bubbles. While resolving this point requires more attention than is possible here, we would start by distinguishing between the uptick rule, which affects small movements in price and therefore also impacts useful arbitrage, and current breakers, which because they are triggered only by large price movements, exclude much "normal" arbitrage from their operation.

70. See supra text accompanying notes 34-62.

71. A recent paper nicely distinguishes between explanations for pricing anomalies that focus on limits to arbitrage as opposed to cognitive bias. Ludovic PHALIPPOU, WhAT DRIVES THE VALUE PREMIUM? (INSEAD Working Paper, Oct. 2003), available at http://ssrn.com/abstract $=360760$ (last visited Nov. 10, 2003). One familiar anomaly is the tendency of value stocks to outperform growth stocks. See supra text accompanying notes 26-31. Taking their expected sides, Fama and French argue that the value effect results from an imperfect asset pricing model, see Fama \& French, Anomalies, supra note 26; Fama \& French, Risk Factors, supra note 26, while Lakonishok, Shleifer and Vishny argue that "value strategies produce higher returns because they bet against strategies followed by most investors, who may extrapolate past earnings growth too far into the future, assume trends in stock prices, or equate a good investment with a well-run firm irrespective of prices,"-a 
this project twenty years ago although, as we confess in the next Part, we were painfully naïve about the level of frictions affecting the professionally-informed trading mechanism. But if this is behavioral finance, then it began with Grossman and Stiglitz. The fanfare seems to us a little late.

\section{How Well Does MOME Stand Up to Behavioral Finance? Good News and BAD}

If, as we claim, MOME is a precursor of some aspects of modern behavioral finance, it is only fair to ask how well MOME's focus on the distribution and cost of information stands up to behavioral finance today. The answer, we believe, is mixed. The good news is that the central categories of MOME, including the market mechanisms and the concept of relative efficiency, are consistent not only with the established empirical findings of behavioral finance but with some of its more promising models as well. The bad news is that back in the early 1980s, we greatly underestimated the institutional obstacles to the production and rapid reflection of information in share prices.

\section{A. The Good News}

The good news about MOME extends to both fact and theory. On the empirical side, proponents of both rational markets and behavioral finance agree that many of the longterm pricing anomalies that cut against the efficiency of market prices largely disappear when analysts control for company size. ${ }^{72}$ These disappearing anomalies include, for example, the underpricing of IPOs and seasoned equity offerings. The size-related character of these anomalies is good news because it is precisely what MOME would predict on the assumption that the size of the float is a critical determinant of the amount and quality of information about issuers, and the relative efficiency with which this information is reflected in market prices. The reasoning is simple. Small issuers have a limited following among analysts and other professional investors, in part because there is little profit to be made by researching issuers whose size restricts the potential gains. As a result, less information is produced, verification of information is more costly, and net returns available to investors and securities traders are lower as a result. ${ }^{73}$

Size, analyst coverage, and the attendant availability can account for pricing anomalies of other sorts as well. On the theory side, an important model developed by

cognitive bias explanation. Josef Lakonishok, Andrei Shleifer \& Robert M. Vishny, Contrarian Investment. Extrapolation and Risk, 49 J. FIN. 1541 (1994). Phalippou, supra, provides a third explanation that focuses attention on limits on arbitrage. Because approximately half of the value effect results from underperformance by growth stocks, not over performance by value stocks, an investor would have to short growth stocks in order to capture the differential. The problem is that some one-half of the most overvalued growth stocks are so small as to have little institutional ownership and therefore could not be borrowed and, it follows, could not be shorted. As to the other one-half of the value differential, Phalippou argues that it results from a small number of stocks with markets so illiquid that efforts to take a significant position would have moved the price of the stock. As we have suggested, limits on arbitrage, rather than cognitive biases, are doing the heavy lifting. See PHALIPPOU, supra note 71 (this note).

72. See Fama \& French, Anomalies, supra note 26; Fama \& French, Risk Factors, supra note 26; Barbaris \& Thaler, supra note 28.

73. Gilson \& Kraakman, supra note 1, at 635-42. 
Hong and Stein ${ }^{74}$ explains momentum trading and skewness in stock prices on the basis of the slow diffusion of private information through the economy. Traders without access to private information rationally treat price movements as a proxy for the injection of new information, which explains momentum trading as well as sudden reversals in price, when traders discover they have already overshot share value. In support of this model, Hong, Lim, and Stein present evidence that momentum trading in shares is particularly strong among small firms and firms that attract little interest among analysts. ${ }^{75}$

\section{B. The Bad News}

If recent models of the production and diffusion of information confirm the continuing relevance of MOME's analysis, our original account of market mechanisms and the institutional production of information suffered from what might be termed "naiveté bias." We implicitly underestimated the institutional complexities that attend the production, processing, and verification of market information, as well as its reflection in share prices. Some aspects of our naiveté were discussed earlier in this essay: in particular, the legal and institutional limitations on arbitrage, including the agency problems that afflict institutional investors-such as the role of incentive structures in encouraging herding behavior by fund managers at the expense of fund investors.

But even more important than underestimating the limits on the arbitrage mechanism, we failed to appreciate the magnitude of the incentive problems in the core market institutions that produce, verify, and process information about corporate issuers. As the Enron cohort of financial scandals demonstrated, lucrative equity compensation has had the side effect of creating powerful incentives for managers to increase share prices. Usually, we suppose, managers respond by creating additional value for shareholders. But sometimes they respond by feeding distorted information to the market —or even by lying outright, as in recent cases such as WorldCom and HealthSouth Corporation. ${ }^{76}$ Similarly, recent scandals demonstrate that we also were too sanguine about the role of the institutions that we termed "reputational intermediaries"-the established investment banks, commercial banks, accounting firms, and law firms that use their reputations to vouch for the representations of unknown issuers, and so reduce the information costs of investors. ${ }^{77}$ As the example of Arthur Andersen's relationship to

74. Harrison Hong \& Jeremy Stein, A Unified Theory of Underreaction, Momentum Trading, and Overreaction in Asset Markets, 54 J. FiN. 2143 (1999) (arguing that if information diffuses gradually, prices will underreact in the short-term).

75. Harrison Hong, Terence Lim, \& Jeremy Stein, Bad News Travels Slowly: Size, Analyst Coverage, and the Profitability of Momentum Strategies, 55 J. FIN. 265 (2000). This account of momentum trading is closely related to the mechanism of "price decoding," as described in Gilson \& Kraakman, supra note 1, at 574-79. A related finding is that the share prices of small and poorly-followed issuers have a positive skew relative to prices of larger companies. Bad information takes longer to enter share prices for smaller firms, possibly because managers of these firms are able to dribble bad news out more slowly than can managers of widely followed firms. (Good news is generally announced immediately). Joseph Chen, Harrison Hong, \& Jeremy Stein, Forecasting Crashes: Trading Volume, Past Returns, and Conditional Skewness in Stock Prices, 61 J. FIN. ECON. 345 (2001).

76. See, e.g., Robert Franks et al., Executives on Trial: Scandal Scorecard, WALL ST. J., Oct. 3, 2003, at 1 (summarizing the history and current status of various corporate scandals)

77. Gilson \& Kraakman, supra note 1, at 604-05, 619-21. 
Enron demonstrated all too clearly, ${ }^{78}$ misaligned incentives and intra-organizational agency problems limit the ability of even the largest reputational intermediaries to police the accuracy of their clients' representations. Finally, we were naïve about the role of security analysts, and particularly those employed by the investment banks on the sellside of the market. ${ }^{79}$ These analysts, it appears, often acted as selling agents for the client-issuers of the institutions that employ them. ${ }^{80} \mathrm{Or}$, put differently, an investment bank's reputation among issuers is likely to matter more to it than its reputation among the lay investors who rely on its analysts' reports.

In sum, on every dimension of information costs - the costs of producing, verifying, and processing valuation data-we confess error by implication, not about the roles of the institutions that supply information to the market, but about how well they perform their roles. The point is perhaps too obvious today to merit elaboration, but the market cannot be more efficient than the institutions that fix the quality and cost of valuation information permit. That, after all, was MOME's principal point.

\section{The Future of Behavioral Finance: Research and Policy Implications}

We have argued that the binding constraints on market efficiency arise, either from institutional limitations or the interaction of the arbitrage mechanism with cognitive biases-not from the widespread existence of cognitive biases alone. There are implications of this view for future research as well as the formulation of regulatory policy.

\section{A. Future Research}

We will not fully understand the import of psychological distortions on the functioning of the capital market until we first understand the institutional limitations on the production and distribution of valuation information. The well-documented list of cognitive biases that motivates much of behavioral finance allows so many degrees of freedom that the framing of testable predictions about real world financial markets is difficult. Fruitful hypotheses will require not only an understanding of cognitive biases but, even more importantly, an understanding of the market processes that screen, channel, dampen, or amplify the biases of traders to produce observed market behavior.

In pursuing this research agenda, the most fruitful topics of investigation are likely to be market frenzies and crashes, such as the 1987 market crash and the recent internet bubble, rather than well-documented pricing anomalies such as the closed-end fund discount or the underpricing of IPOs. The evidence suggests that the traditional anomalies-the usual suspects-can be comfortably explained within the MOME framework as a function of institutional limitations on the operation of the mechanisms of market efficiency in the course of "normal trading," including limitations on the ability of informed traders to engage in arbitrage. We know much less about the institutional and psychological underpinnings of bubbles and crashes. On one hand, the attractions of

78. See, e.g., Robert Franks et al., supra note 76; John C. Coffee, Jr., Understanding Enron: "It's About the Gatekeepers, Stupid," 57 BUS. LAW. 1403 (2002).

79. See Gilson \& Kraakman, supra note 1, at 601 (suggesting securities analysts work unambiguously to reduce the processing costs of information for the market).

80. See, e.g., Robert Franks et al., supra note 76. 
psychological hypotheses are greatest for explaining such unusual or violent market behavior. As we suggested in Part IV, above, the price effects of cognitive pathologies are likely to be episodic: associated with bias, surges of individual trading, and extraordinary breakdowns in the arbitrage mechanism. This scenario fits nicely with the periodic appearance and demise of market bubbles. On the other hand, there is a competing body of literature pointing to institutional pathologies that can generate seemingly irrational market disturbances even without the help of noise traders. ${ }^{81}$ If the study of market institutions teaches anything, it is that not every instance of collective irrationality is necessarily rooted in individual irrationality.

\section{B. Policy Implications}

Given the limits of our knowledge at the moment, it is useful to ask about the policy implications that follow from the progress that behavior finance has made or is likely to make in the foreseeable future. These implications, it seems to us, fall into two categories: those in which behavioral finance holds promise for guiding regulatory policy and those in which it does not.

\section{Where Behavioral Finance Can Guide Reform}

We see two principal areas where behavioral finance is likely to have policy implications in the near term. One lies on the institutional side. Given the importance of limitations on the arbitrage mechanism that we have emphasized thus far, regulators should clearly seek to reduce legal and institutional barriers to arbitrage. Thus, the SEC should consider removing the uptick rule and margin requirements that burden shortselling, ${ }^{82}$ as well as campaigning against the lingering taint that makes institutional investors such as mutual funds reluctant to pursue short-selling strategies. Far from being suspect, short-selling actually confers a positive externality on the entire market by speeding the reflection of unfavorable information in share prices. In addition, behavioral finance may support temporary interventions in the market, such as trading halts, when market behavior suggests a surge of biased trading that threatens to destabilize arbitrage. We hesitate to make this prediction too forcefully, however, as there is still much work to be done in parsing out the psychological and institutional roots of market frenzies.

We are far more confident about a second area in which behavioral finance might eventually inform regulatory policy: the protection of individual investors. The possible consequences for policy involve paternalistic responses to cognitive bias. As we argued above, three conditions must be met for psychological distortions to affect share prices: (1) cognitive biases must be pervasive (as most commentators believe they are); (2) they must be correlated (because otherwise they are offsetting); and finally, (3) the arbitrage mechanism must fail with respect to their effects. Notice, however, that cognitive bias can injure investors even if it has no effect whatsoever on share prices, i.e., conditions (2) and (3) are not met. ${ }^{83}$ Perhaps the best example is the employee who, as a result of

81. See, e.g., Chen, Hong, \& Stein, supra note 49; Rubenstein, supra note 31; and Bulow \& Klemperer, supra note 58.

82. See supra text accompanying notes $43-45$.

83. Samuel Issacharoff, Can There Be a Behavioral Law and Economics?, 51 VAND. L. REV. 1729, 173334 (1998), puts forward similar criteria in assessing the application of the cognitive bias literature to law and 
limited knowledge or cognitive bias, misallocates investment in a $401 \mathrm{k}$ plan by failing to diversify her investments, or assumes a level of risk inappropriate to her age and retirement aspirations. As Howell Jackson's paper in this symposium points out, ${ }^{84}$ the rise of defined contribution and voluntary investment plans has shifted discretion over retirement savings from professional traders to individual "lay" investors, who are often noise traders as well. It might well be, then, that we would be wise to limit the investment discretion of these employee-investors, precisely in order to prevent them from harming themselves. Such limitations might be mandatory for government-sponsored or taxfavored retirement plans: for example, an inflexible diversification requirement. Alternatively, these limitations might take the form of what one group of authors has termed "asymmetric paternalism," 85 i.e., default rules that sophisticated investors can avoid but that are binding on unsophisticated investors who are more likely to make costly errors as a result of cognitive bias or bounded rationality.

\section{The Limits of Behavioral Finance as a Policy Tool}

Once we leave the easy cases of short-selling restrictions, obvious market frenzies, and undiversified retirement savings, the legal implications of behavioral finance for corporate and securities law become much murkier for the simple reason that we know little about both the extent and nature of cognitive bias among traders or the interaction of cognitive bias with the institutions that generate information and the mechanisms that reflect it in price (including, above all, the arbitrage activity of sophisticated investors). We therefore find ourselves largely in agreement with Donald Langevoort's assessment of the implications of behavioral finance for securities regulation, ${ }^{86}$ which, no doubt over-simplifying, we would summarize as, "not much so far, although lawmakers should stay tuned to current research and keep an open mind." Indeed, we would go one step further, to caution against the use of behavioral finance to advance policy agendas that it cannot possibly support. We close this essay with the cautionary example of a policy debate in which behavioral finance is sometimes said to have important implications when in fact it does not.

\section{The Takeover Debate and the Limits of Behavioral Finance}

The example we have in mind is the claim that is sometimes made in debates over takeovers that investor irrationality demonstrates the wisdom of vesting discretion over the decision to defend against hostile takeovers in the hands of managers rather than shareholders. ${ }^{87}$ We find this claim unpersuasive for several reasons that nicely illustrate

economics more generally.

84. See Howell Jackson, To What Extent Should Individual Investors Rely on the Mechanisms of Market Efficiency: A Preliminary Investigation of Dispersion in Investor Returns, 28 J. CORP. L. 671 (2003).

85. Colin Camerer et al., Regulation for Conservatives: Behavioral Economics and the Case for "Asymmetric Paternalism," 151 U. PA. L. REV. 1211 (2003).

86. Donald C. Langevoort, Taming the Animal Spirits of the Stock Markets: A Behavioral Approach to Securities Regulation, 97 NW. U. L. REV. 135 (2002).

87. For the most recent rematch-it may feel to some like Rocky $X X X$-see, for example, Ronald $\mathbf{J}$. Gilson, Unocal Fifteen Years Later (and What We Can Do About It), 26 DEL. J. CORP. L. 491 (2002) (analyzing the use and development of Unocal); Lipton \& Rowe, supra note 63; Ronald J. Gilson, Lipton and Rowe's Apologia for Delaware: A Short Reply, 27 DEL. J. CORP. L. 37 (2002) (replying to Lipton and Rowe's response 
the limits of cognitive psychology in setting basic corporate policy. In the first place, market efficiency has a limited role in the takeover debate. The primary policy tradeoff is between the absence of strong form efficiency-the possibility that managers have information about the corporation's value the market lacks, which is the reason for giving management discretion to defend-and the possibility of managerial agency cost, the reason for giving the decision to shareholders. This one comes out in favor of shareholder decision-making because target management can always ameliorate the failure of strong form efficiency by disclosing its information if takeover decision making is allocated to shareholders, ${ }^{88}$ while allocating authority to management does nothing to ameliorate the agency cost problem. ${ }^{89}$

It is at this point that the cognitive bias component of behavioral finance comes into play: the balance may shift if, despite disclosure, shareholders will predictably reject target managers' advice because of one or another cognitive bias. ${ }^{90}$ Of course, given the range of cognitive biases one cannot entirely reject this possibility. As we suggested above, some biases predict that shareholders will tender too readily while others predict an unwarranted reluctance to tender. ${ }^{91}$ In the context of the allocation of takeover decision-making between managers and shareholders, however, the critical point is that cognitive bias analysis be applied on a bilateral or comparative basis.

This concern grows out of the fact that the experimental literature is largely unilateral in its focus. The experiments are concerned only with whether a particular decision-maker is subject to a cognitive bias, not whether one competing decision-maker is more impaired than another. But when cognitive bias is invoked to allocate authority among competing decision-makers, the analysis must be bilateral; the potential biases of the decision-makers must be compared. In our context, the question is: whether managers' or shareholders' decisions are likely to be more distorted?

The comparison seems to us to favor allocating decision-making authority to shareholders. First, it is simply unclear which, if any, biases are likely to apply to individual shareholders when they must choose whether to accept a hostile offer. Moreover, the outcome of the takeover is likely to be determined by the decisions of institutional investors, who are less likely to be subject to cognitive biases (but may be subject to institutional influences). The shareholders critical to the outcome of a hostile takeover look little like the noise trader clientele of closed-end mutual funds. ${ }^{92}$ Finally, the market for corporate control operates, to an extent, as a backstop in case cognitive biases nonetheless cause target shareholders to tender into too low an offer. The ubiquity of competing bidders emerging in response to an underpriced offer can save the

to the author's analysis of the fifteen-year history of Unocal) [hereinafter Gilson, Apologia]; Martin Lipton, Pills, Polls, and Professors Redux, 69 U. CHI. L. REv. 1037 (2002) (discussing the evolution of the law of corporate takeover); Lucian Bebchuk, The Case Against Board Veto in Corporate Takeovers, 69 U. CHI. L. REV. 973 (2002) (arguing that boards should have no veto power against takeover bids after shareholders' choice is ensured).

88. The problem cannot be completely eliminated by disclosure because target management may have difficulty establishing the credibility of its disclosure of information suggesting a higher target value.

89. See Gilson, Apologia, supra note 87 , at 42 .

90. Perhaps this is the unarticulated justification for the Delaware Supreme Court's concern that shareholders will be subject to "substantive coercion."

91. See supra text accompanying notes 63-65.

92. See supra text accompanying notes 35-36. 
shareholders from their biases.

On the other side, one can imagine a range of biases that may influence target managers to resist a hostile takeover even when the transaction is in the shareholders' best interests. A reaction to cognitive dissonance may cause managers to respond to an offer that calls into question their performance and competence by deriding the bidder's motives and promising a brighter future if only the shareholders have patience. Managers may genuinely believe their claims, but behavioral finance suggests that their assessment may be driven by a cognitive bias. ${ }^{93}$ This effort at dissonance reduction may, in turn, be exacerbated by the overconfidence bias-managers' vigorous defense may be encouraged by a biased assessment of their own skills. Other examples are possible, but the point by now should be clear: when cognitive bias analysis is invoked to illuminate the choice between two decision-makers, its application must be bilateral.

In all events, we conclude that the cognitive bias element of behavioral finance is unlikely to change the trade off between agency costs and strong form market inefficiency that we believe supports allocating the choice whether a hostile takeover goes forward to shareholders. To be sure, by highlighting the possibility of good faith but systematically misguided defensive action, the cognitive bias analysis does serve to give richness to the explanation for target managers' behavior that agency theory's simple self-interest paradigm lacks. ${ }^{94}$ But this useful insight reinforces, rather than undercuts, an allocation of decision-making authority to shareholders.

\section{CONCLUSION}

So where does our retrospective leave us? Twenty years further, we think, along the road leading from elegant models of the workings of the capital market in a frictionless world, to an understanding of how the market operates in a world where information is costly and unevenly distributed, agents are self-interested, transactions costs are pervasive, and noise traders are common. The nature of this more realistic understanding

93. Gilson, Apologia, supra note 87 , at 46 . Put differently, where self-interest and cognitive bias move in the same direction, one might expect the buildup of significant momentum.

94. To be sure, one can create a model in which this outcome may be different. For example, Andrei Shleifer and Robert Vishny proffered a model in which takeover activity in the 1970s, 1980s, and 1990s can be explained by market inefficiency. The model, however, makes some extreme assumptions. First, the market is assumed to be dramatically inefficient, either badly over or undervaluing a company's stock, while managers are assumed to be completely rational and understand precisely the way in which the market is inefficient and are also able to predict the long-term value of their companies and the companies they purchase. Next, the managers are assumed to maximize their personal objectives given their own time horizons. In effect, the model requires both market inefficiency and enormous agency costs. ANDREI SHLEIFER \& ROBERT VISHNY, STOCK MARKET DRIVEn ACQUisitions (Nat'l Bureau of Econ. Research, Working Paper No. 8439, 2001). An effort to empirically test the Shleifer and Vishny model presents interesting results. MING DONG, DAVID HiRSChleifer, SCOTT Richardson, \& SiEw HONG TEOH, DOES INVESTOR Misvaluation Drive the TAKEOVER MARKET? (Working Paper, Feb. 27, 2003). While the paper's econometrics and results are too complicated to discuss in detail here, we note that the results are consistent both with some level of market irrationality and with a combination of bidder management agency behavior serving as a correcting signal of strong form inefficiency. Moreover, the analysis reflects conflicting assumptions about what markets and individuals know and do not know that affects both the empirical tests and the assessment of their results. In all events, the outcome does not speak in favor of allocating decision-making authority to target management. 
is beginning to take shape, and it can be described in a single word: messy. There are a lot more moving parts with, as a result, a much larger number of interactions to understand. Models will be necessarily partial, illuminating particular interactions but far short, and without the ambition, of a unified field theory. That said, we come away with some confidence in a number of themes, some that were explicit in MOME, some that we missed, and others that reflect an assessment of the likely contribution of cognitive psychology to our understanding of how the capital market functions.

First, as was explicit in MOME, we believe that understanding the structure of institutions is central to understanding the operation of the capital market. MOME's shortcoming was the failure to drill deeply enough into the incentive and agency structure of important market institutions like those through which arbitrage is carried out. To the large extent that behavioral finance is composed of applying agency information and incentive analysis to capital market institutions, it promises to deepen our understanding of how the capital market operates in the real world.

Second, we are skeptical that the new focus on cognitive biases in the end will. explain very much about price formation, except in circumstances in which the biases of investor biases both coincide and give rise to increased participation. Thus, we expect that this component of behavioral finance will have a limited role in the market efficiency debate. In contrast, this literature can be quite important in circumstances where we care about the consequences of biased decision-making on the decision-makers themselves, independent of whether aggregate price levels are affected. Reform efforts directed at individuals' decisions with respect to pension investments, as with $401 \mathrm{~K}$, provide a good example.

Our final theme is one of balance. When cognitive psychology is used to analyze issues relating to the allocation of decision-making between competing parties, the application must be bilateral and comparative. Demonstrating one party's cognative bias merely begins the analysis; to complete the analysis this bias must be compared to those of alternative decision-makers. As we suggested in our analysis of the application of cognitive bias analysis to tender offers, the fact that shareholders may have a bias in deciding whether to tender does not demonstrate that managers should have the power to block an offer. Rather, the shareholders' bias must be compared with those biases that affect management.

Twenty years after publication, we remain comfortable with the analytic framework that animates MOME. We should have been more skeptical of market institutions then, but skepticism grows with age. 